\title{
Chapter 9 \\ Changing the Culture of Policing: A Moral Imperative!
}

We want to turn to another major crisis that demands our serious attention. Not only is it important in its own right, but it reveals other important factors that bear on the nature of complex messy Systems.

It also demonstrates a key point that we've been making throughout, namely, that no major crisis ever happens in isolation. Every crisis is influenced by what is going in the larger society of which it is a part. Thus, even though in the strict sense they have not caused one another, they have a strange way of interacting with other crises and thereby intensifying one another. Indeed, the very fact that millions were forced to stay home because of the Coronavirus allowed many for the first time to see a prominent instance of where a Black man was killed for no apparent reason other than the fact that he was Black.

Given the completely unjustified and wanton murder of George Floyd, the calls for real and long-lasting change in the culture of policing have never been more resolute. (The recent shooting of Jacob Blake in Wisconsin has only intensified the outrage.) It couldn't be any clearer that policing won't survive without serious reforms. ${ }^{1}$ But other than the seemingly endless calls for change, concrete proposals for how in fact to achieve it are conspicuously absent.

For this reason, based directly on Kilmann's work, ${ }^{2}$ we want to describe a specific process that has proven highly successful in changing the culture of individual organizations and how it needs to be modified to combat structural and systemic racism with regard to policing.

First of all, the culture of organizations is so powerful that it accounts for up to $80 \%$ and more of what goes on. No wonder why it's so hard to change. Even if you got rid of all of the current participants and replaced them entirely, in no time at all

\footnotetext{
${ }^{1}$ See Laurence Ralph, "To Protect and to Serve: Global Lessons in Police Reform," FOREIGN AFFAIRS, September/October 2020, pp. 196-202.

${ }^{2}$ text
} 
you'd hear the same exact conversations and witness the same behaviors again and again.

In short, culture is the very lifeblood of an organization. It extends far beyond the private desires and inclinations of its individual members. It causes people to go along with actions and put up with policies even when they violate their deepest values and convictions.

Given that it's largely taken for granted and rarely discussed, one of the biggest difficulties is that the culture of most organizations is largely invisible and silent. Essentially, it spells out "how everyone is expected to act toward one another and its constituents, basically, how we do things around here, how to defer to those in authority, how to treat subordinates, how to dress and speak if one is to be taken seriously, etc." The clear but unwritten message is "If you want to make it around here, then you'd better get on board, learn the 'rules of the game' as quickly as possible, and play along like everyone else, or you'll be ejected so fast that you won't even know what hit you!"

Changing the culture of an organization necessitates surfacing the actual behavioral norms or "current rules of the game" that govern its everyday behavior, and then comparing it staunchly with the ideal or desired behavioral norms that are necessary to achieve the organization's stated mission. Most organizations have never done it before, certainly not explicitly and systematically. The larger the gap between the actual and desired norms, the greater the effort that's required to close it and thereby change the culture.

The oft-stated, desired norm of policing is "to serve and protect the public equally without regard to class, ethnicity, race, religion, sexual preference, or social standing." Further down on the list, if at all, is "to report unacceptable behavior in one's fellow officers as quickly as possible to one's superiors." Deplorably, it's taken the death of George Floyd to force a number of departments to abandon chokeholds and to require officers to report immediately violations of acceptable police behavior.

In practice, the actual norms often deviate substantially from the desired norms. Not only are different members of the public treated differently, but the primary message is "Don't rat on your fellow officers!" If you do, then "Don't expect them to show up, protect your back, and cover your a\$\# when you need them most." In this way, the System closes ranks to protect itself first even though primarily it's supposed to protect the general public.

Fundamental change requires that an organization be both willing and able to list the real norms that govern its actual day-to-day behavior and then to specify the detailed and specific actions it's willing to undertake both rigorously and Ethically to enforce the desired behavioral norms that are fully aligned with the organization's basic mission. Those who break the new norms will not only be called out for unacceptable behavior, but will be reprimanded appropriately, either demoted or fired, and in the worst cases, tried for criminal offenses.

Primarily, the organization itself has to specify the ways in which the new norms will be strictly enforced. Although necessary, creating and enforcing new behaviors cannot be imposed entirely from the outside. (As we show, this has to be modified 
to achieve systemic change with regard to policing.) Police officers themselves must be the principal participants in the design and management of their own "sanctioning system" by indicating exactly what will happen when someone violates one or more of the new desired norms. In this way, hopefully they will "own" the new behavior.

Ironically, since they are the ones who are in the best position to observe how and when the new norms are being violated, the police must police their own culture. However, no matter what, some will hang onto the old, dysfunctional norms, whether out of habit, fear, or just plain spite.

Real cultural change also needs to be reinforced by additional training, e.g., in conflict management via the TKI and how to diffuse tense situations, in particular teamwork that encourages the open expression of differences, and a formal performance appraisal system that can further sanction and reward new norms. However, we cannot emphasize enough that real culture change must precede any attempt at further training, team development, and changes in the reward systems. Otherwise, they will only produce more lip service, not real behavioral change where it's needed most.

Even though we've seen dramatic cultural change take place in a wide variety of organizations both public and private, because of the special nature of police work, just raising the topic of culture change is especially challenging, if not out-and-out threatening. This is especially the case since policing frequently involves instant life-and-death situations, which is obviously not the case in other organizations. Due to the ever-present stress and tension between protecting oneself and that of others, and especially not hurting innocent people, the life-and-death, split-second decisions that police officers always face present major challenges. Nonetheless, there are clear signs that serious change is afoot. Once again, several departments have declared their willingness to abandon chokeholds.

Still, we have no illusions whatsoever that it will be easy. An article in The New York Times says in no uncertain terms that police unions are the staunchest defenders of the current culture of police behavior. ${ }^{3}$ And an article in The New Yorker only reinforces the point. ${ }^{4}$ Thus, it's not just a matter of changing the culture of individual departments, but in those organizations that are closely aligned as well.

Changing the institution as a whole is even more daunting. It not only requires that national police organizations be willing and are able to do to what individual organizations are, but that a number of them need to meet regularly to share the gaps they have uncovered and what they are doing to close it. In other words, it requires a Systems-wide effort to change the System as a whole. It has to be sustained by means of frequent meetings and constantly updated action plans.

But something even more is required to combat systemic racism. First of all, representatives of small-, medium-, and large-sized departments need to meet

\footnotetext{
${ }^{3}$ Noam Scheiber, Farah Stockman, and J. David Goodman, "Fierce Protectors of Police Impede Efforts at Reform," The New York Times, Sunday, June 7, 2020, p1 and 22.

${ }^{4}$ William Finnegan, "The Blue Wall, The police and their unions in the wake of the protests, "The New Yorker, August $3 \& 10,2020$, pp. 48-57^.
} 
regularly. The challenges they face are not necessarily the same. For this reason, they need to share on a frequent and timely basis what's worked in changing the culture of their respective organizations, what hasn't, and why. In particular, special attention needs to be given to the different sanctioning Systems, what if anything they share in common, and what can be modified for their individual situations.

Since we cannot wait for every department far and wide to go through the same process, there is no realistic alternative but to issue a Systems-wide mandate to demand that what's worked for other departments be adopted universally. Indeed, a new Federal Commission needs to be fashioned that will assess how well police departments nationwide are complying with the new directives. Furthermore, there need to be clear penalties for the failure to comply on a timely basis.

Nonetheless, we wouldn't expect the sanctioning policies of different Stakeholders to be in agreement. We would in fact expect the policies of Mayors, Police Commissioners, Civilian Review Boards, and the Police themselves to disagree, often sharply. For example, sanctions are expected to differ with regard to the kinds of situations requiring the use of force and what types are appropriate. The general issue is how far individual police officers are allowed to depart from the new norms, not give their full support, and what the resultant punishments will be.

One of the key jobs of the new Federal Commission is the training of Federal Mediators, if need be Federal Judges, who will have the final say in the determination of particular sanctioning systems. Again, it's entirely unrealistic to expect that all of the parties concerned will go along with any System that's proposed. Serious negotiations are also expected to take place with regard to the training and involvement of Mental Health Experts, Social Workers, and others who can accompany the police as needed.

In sum, embracing serious culture change must be the rule or the future of policing everywhere is in danger. Nevertheless, anyone who thinks that modern, complex societies can survive without the police is seriously misguided. If anything, more funding, not less, is required for serious and long-lasting change.

Open Access This chapter is licensed under the terms of the Creative Commons Attribution 4.0 International License (http://creativecommons.org/licenses/by/4.0/), which permits use, sharing, adaptation, distribution and reproduction in any medium or format, as long as you give appropriate credit to the original author(s) and the source, provide a link to the Creative Commons license and indicate if changes were made.

The images or other third party material in this chapter are included in the chapter's Creative Commons license, unless indicated otherwise in a credit line to the material. If material is not included in the chapter's Creative Commons license and your intended use is not permitted by statutory regulation or exceeds the permitted use, you will need to obtain permission directly from the copyright holder.

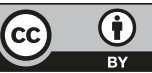

